\title{
The spatial politics of gender in EAP classroom practice
}

\author{
Abstract \\ This paper explores some of the challenges faced by EAP teachers as they \\ address gender issues that arise when teaching in a non-Western cultural \\ context. It draws on interviews with four Australian teachers regarding their \\ experiences in delivering EAP programs in East Timor as part of the \\ international aid effort, and focuses on critical incidents in which gender was \\ perceived as an issue in classroom practice. The paper discusses the ways in \\ which teachers were navigated the competing claims of gender equity and \\ cultural sensitivity in the pedagogic domain of the classroom. Four spatial \\ paradoxes that frame the teachers' narratives are presented as a counterpoint to \\ conventional discourses of development, EAP and gender equality as temporal \\ narratives of progress.
}

Keywords: English for academic purposes; Gender; Space; Teacher narratives

\section{Introduction}

Pragmatic approaches to EAP have traditionally meant that political issues of students’ and teachers’ subjectivities and lived experiences have received little attention in mainstream EAP research and practice, where notions of context and relevance have mostly been concerned with acculturation to institutional academic standards and instruction towards discipline-specific written 'products' (Belcher, 2006, p. 149). More recently, however, critical scholars have attended to the complex relationship between EAP and a broader, dynamic notion of context (Benesch, 2001; 
Pennycook, 1997; Singh \& Doherty, 2004), within an educational agenda that aspires to social and political engagement, critique and even transformation. However, as Hyland and Hamp-Lyons (2002, p. 10) noted in their opening article in this journal, EAP has "yet to seriously confront" the issues that arise from an interest in language and power in this broader social context, and "effective classroom responses are often constrained by the institutional contexts in which we work”. It is one aspect of this complex relationship that I seek to explore, by focusing on the ways in which EAP teachers perceive and respond to incidents in which gender arises as a dynamic aspect of intercultural classroom life.

This paper draws on data from semi-structured interviews with four female teachers and discusses their responses to gender issues that arose in their classrooms. The teachers' narrative accounts raise questions regarding the conflation of English and 'civilised' notions of gender equality, the division between public life and private experience, and the role of the EAP teacher in pursuing emancipatory politics. All four teachers were teaching EAP in a context that is not widely discussed in the literature concerning English language teaching, but which nevertheless in many ways exemplifies key issues at stake in a critical analysis of EAP. The teachers, ranging in age from late 20s to mid 50s, were employed by Australian non-government organisations responsible for delivering development aid programs in East Timor. Elly ${ }^{1}$ and Dana taught EAP to university students in Dili, the capital city; Kate and Jane taught EAP to in-service school teachers in a major regional town. Although some of their students aspired to studying in an English speaking country at some

\footnotetext{
${ }^{1}$ Pseudonyms are used for all participants
} 
time in the future, most used English to further their studies or professional activities in East Timor.

In this paper, I first situate the classrooms within the broader context in which the teaching took place. Next, I discuss four critical incidents that arose in the course of classroom teaching. These incidents are discussed in the light of several paradoxes that shape the negotiation of gender issues in the development classroom. The incidents or events are regarded as 'critical' in that they not only reveal something of the workings of gender relations in classroom life, but also point to certain contradictions that surface as a range of gendered discourses are played out in an intercultural EAP ‘contact zone’ (Pratt, 1992). As key sites in global education, EAP contact zones have been "historically constituted" in relation to "neocolonial practices” and the "global spread of English language and Western knowledge"; the power relations produced in these sites are also "reconstituted and contested in day-today pedagogic interactions” (Singh \& Doherty, 2004, p. 11-12). The interview extracts discussed here are drawn from a larger research study of female EAP teachers' experiences of living and working in international development. That study sought to extend understandings of how English language teaching fits into the world of international development, and how English language teaching in development is experienced through gender and race.

\section{Spatial politics in EAP, gender and international development}

The context of international development may appear to be a world apart from the usual 'First World' circumstances in which most studies of gender and language teaching have been located (Sunderland, 2000). Nevertheless, the international 
development context bears similarities with many other contemporary EAP sites where increasing numbers of students participate in "global university contact zone[s]” in which teachers and students from different cultural backgrounds interact, and where identification of appropriate cultural norms is open to question (Singh \& Doherty, 2004, p. 9). In order to better understand the perceptions and difficulties faced by teachers in the present study, I will outline here some aspects of international development that are relevant to the context in which they worked.

The discursive framework of international development, realised in mainstream, neoliberal development policies, establishes what I have called elsewhere a temporal narrative of progress (This Author, 2006) that assumes an advancing social and economic order along the lines of modernist Western development. According to this time-oriented framework, Western nations have set an agenda of social and economic progress that can be profitably deployed as a model for producing similar advancements elsewhere. The teaching of English language for academic purposes falls neatly into this temporal narrative, particularly when those skills are targeted at improving technical and vocational capabilities with the broader aim of enhancing the participation of emerging economies in the global marketplace (see, for example, AusAID, 2007a). Promoting gender equality as a feature of time-oriented social progress has also, in recent decades, been an important aspect of international development policies. Through 'gender mainstreaming', the goal of gender equality is supposedly incorporated into the design, delivery and evaluation of all development programs (Mazurana et al, 2005; and see, for example, AusAID, 2002, 2007b). 
In contrast with the social progress agenda of official development policies, critical scholarship suggests that international development is a site for the reproduction of historical, colonial conditions of inequalities (Escobar, 1995; Spurr, 1993). These inequalities are evident in several fields, including the processes and outcomes of English language teaching (Pennycook, 1994, 1998, 2001; Phillipson, 1992), and in the intensification of gender dichotomies (Stoler, 1995; Mohanty, 2003). Of particular relevance to the latter are the conditions of 'hypermasculinity' which arise in the increasingly common situations where international development has been located in sites of political instability and in the presence of military intervention or peacekeeping (Bowcott, 2005; Mazurana et al, 2005; Thomas, 2004; Wells \& McEwan, 2004). In the case of East Timor, international military intervention has accompanied several phases in the new nation's process of independence since 1999, and has produced conditions of militarisation that inflect the conduct of humanitarian and development programs (East Timor Institute for Reconstruction Monitoring and Analysis, 2001; Enloe, 2000; Mazurana, 2005).

There are, in addition, certain key tensions, identified in critical, feminist and postcolonial approaches to education, which I have used to frame my exploration of teachers' accounts of EAP in this context. These are tensions that I conceive as spatial paradoxes, that is, paradoxes that trouble the modernist, time-oriented organisation underpinning educational institutions and endeavours, especially in international development, and that take up the notion that the social, political and spatial are mutually constituted (Massey, 1994). Together, they comprise a spatial politics of gender in EAP, an alternative to the temporal politics of language education and development that risks sustaining unquestioned notions of Western cultural 
superiority. In relation to teaching practice, the first paradox concerns the tension between authority and nurturance in pedagogical relations (see, for example, Luke \& Gore, 1992); the second specifically affects the position of the 'Western' teacher in the 'Third World' context, and relates to the competing claims of gender equality and cultural sensitivity (Mohanty, 1988, 2003). The third concerns the conflict between male-female gender relations and teacher-student pedagogical relations within the classroom (Gallop, 1995); the fourth concerns interaction of public, institutional space and personal, private space and the ways in which these interact in educational domains (Luke, 1992, 1996). These four paradoxes come into play in the space of the EAP classroom, where Western teachers are charged with a complex development agenda: on the one hand, the task of acculturating students to (foreign) academic norms; at the same time, the task of advancing principles of gender equity, while remaining mindful of the potential of cultural (and feminist) imperialism associated with the teaching English.

\section{Critical incidents in EAP, gender and institutional authority}

I turn now to a discussion of how the female teachers in my research context represented gender in their language teaching practices. None of the teachers professed to focus on gender as an issue, confirming Sunderland's observation that gender rarely figures in language teachers’ reflections on classroom practice (2000, 2004). Gender nevertheless emerged in narratives of certain events where it was tied in with other axes of difference such as age, ethnicity, economic status, political allegiance and institutional affiliation. In my exploration of teachers' accounts, I focus on how female teachers performed with authority, how questions of cultural difference were negotiated in conjunction with gender, and how gender relations were 
perceived as an issue in the language classroom and beyond. Rather than demonstrating a singular argument or a clear understanding of gendered spatiality in the classroom, these stories point to the very complexity of an institutional space where different cultures and expectations of authority and gender intersect. They generally move from images of authoritative spatial control, to images of a fragile and constrained spatial authority.

\subsection{Elly: authority and nurture}

OK, gender wise [...] a minority of students in the class were women, and they tended to defer to the blokes, in the sense that the guys'd get on the [limited number of available] computer and just tap away and the women'd just sit back a little bit. But also, the women were often also running households at home and trying to feed kids and doing all that sort of stuff as well [...]

We instituted a half-half rule, so when half time was up they would change seats [at the computer], so most of them would go with that, a couple of guys would hang on and hang on and hope that I wouldn't notice and the girls wouldn't say anything. And I'd just go over and chuck 'em off their chairs and put the women in the seat (Elly).

In classroom activities where equal access to educational resources was seen as a inequitable, Elly felt comfortable in using her authority to oppose what she saw as relatively straightforward examples of gender imbalance and to reorganise the classroom space and time to enable greater equality. This authority could be seen as a product of the mutual constitution of social and spatial relations within the institution 
and the classroom, where the power to author spatial control is vested in the teacher (Luke, 1996). However, in thinking through these authoritative interventions, Elly pointed to some of the doubts that troubled her in this simple exercise of authority.

Like many of her colleagues, Elly had distanced herself from the patriarchal relations she perceived in the development context, where gender, racial and economic hierarchies characterised interactions both within the international development community and between the international and Timorese communities. In her teaching position she had expressed a desire to break down the hierarchies that positioned her above her students, and to value her students through a more democratic pedagogical relationship. In this desire to be 'in there, proving my commitment to them', Elly demonstrated her identification with a nurturing pedagogy associated with the 'march of progress’ from an authoritarian, teacher-centred discipline towards a more 'natural', learner-centred model of teaching (Jones, 1990; McWilliam, 1999), and a gender shift from a patriarchal to maternal model of pedagogy. While this approach emphasises “a decentering of the teacher’s position, while students gain greater control of the classroom” (Norton \& Pavlenko, 2004, p. 511), it has been accused of allowing existing structural inequalities to continue unchallenged (see, for example, Ellsworth, 1989). In contrast, Elly’s authoritative intervention into classroom gender dynamics enacted a more teacher-centred agenda, working openly against what she perceived as social injustice. In these incidents, Elly's actions were centred on the relatively autonomous domain of a classroom, where she could assume the authority to act in favour of "feminist normative visions of 'the good' and socially just" and, with the institution of simple rules, to lead students to "see themselves and the world through different, and more (en)light(ening) lenses” (Luke, 1996, p. 291). 
Nevertheless, for Elly, the possibility that the imposition of gender-equality practices may contradict Timorese cultural norms led to 'all sorts of contradictions in my head [...] I don't know the answer to this one. This is like a cultural relativism versus human rights argument, and I never know what to think'. In thinking through this dilemma, Elly drew on her belief in Marxist ideology. She reasoned that eventually gender equality would come about in East Timor as a result of 'social and economic transformations' in the 'phases of development', thus viewing women's development within the framework of teleological progress. At the same time, she acknowledged that despite foreign teachers' introduction of gender-affirmative, equal opportunity practices, these may well have achieved little in terms of addressing the underlying economic, cultural and political structures that hold women in a particular position within a society.

I think that introducing some of those ideas, whether they get adopted now by say Timorese communities or not, is as much of an intervention as can be made. [...] But it doesn't surprise me at all that, you know, [hearing] that the [international agencies] withdraw and the village groups go back to their traditional ways, because none of the social structures have changed.

In this sense, the teacher was caught between public policy rhetoric that might insist on a formalised meaning of equality and access, and cultural structures that appeared to be organised along different lines. Of course, as the gender disparities within the international development community demonstrated, social equality may not necessarily follow from economic development, and in any stage of economic 
development it is characteristically women who are working or studying and 'also running households at home and trying to feed kids and doing all that sort of stuff as well'. In both developing and developed societies, women maintain responsibility for the reproductive role of society despite gaining access to the public domain of productive labour (Luke, 1992).

\subsection{Kate: gender and culture}

Elly's authority to organise the space of the classroom according to liberal ideals of gender equity was apparently received with only mild resistance, as some of her male students lingered in their seats. However, greater difficulties arose where the gendered meanings of spaces outside the classroom interacted with the educational domain, where issues of gender equality confronted issues of cultural difference, and where the public/private division of gendered space overlapped. The EAP discourses that Kate drew on were those that presented Western language teaching qualifications and methods as more advanced than those practiced in East Timor, thus validating her role as a Western expert assisting the progress of development. The demonstration of 'modern' teaching methods for EAP was the primary organising principle of her lessons, with elements arising from the immediate context, such as issues relating to gender or cultural difference, slotted into the spaces provided in the lesson sequence.

One situation recalled by Kate suggested how a particular lesson was planned to demonstrate a mixture of textual genres and teaching methods, and by chance coincided with one of the religious festivals in East Timor: 
We went into 'procedures', so we did it as a 'recount' of our own experience, a language experience approach, and then converted it to a procedure thing, a recipe, for Shrove Tuesday [a Catholic celebration], which turns out is a big deal up there.

Since the teaching method was to be 'hands-on' and 'experiential', the class shifted from the conventional classroom to the domestic space of the home, a move that raised particular aspects of the gendered meanings of space. In this account the teacher's authority to organise the teaching and learning space of the classroom was also carried over into the domestic space of the home:

I invited them to all come to the house where we were living and I got all the resources and we made pancakes, and I made a little bit of a cross-cultural faux pas, with insisting that everybody had to participate at all levels and that included the men washing up. [...] Carlos's eyes got as big as saucers, 'You want me to do the washing up?!'

At this point, with Carlos indicating his resistance to Kate's directions, a number of different cultural discourses clustering around the event could have been invited into the discussion, and formed the basis of open inquiry. Yet, in Kate's recollection, only one cultural perspective was made available:

I said [flippantly] 'yeah, everybody can have a go' [laughs]. So I just made the point that if you're doing this sort of thing you just have it as an across the board rule that everybody has to wash their hands, everybody has to have some hands-on 
experience and participate, and that includes the cleaning up, and you don't get toI said this is an English lesson, so although maybe it's culturally inappropriate in Timorese society, if we're exploring English and Australian styles of education it's something to explore.

So I didn't impose it that it was better, I usually- and I probably told them that line too that, in Taiwan I very strongly said that it wasn't Western education practice or business practice was better than their style, but I wanted them to know how to eat with a knife and fork as well as with chop sticks, and to choose when it was appropriate to do it either way. So that got over a few humps in Taiwan, and I think I used the same story up there [in East Timor]. But I- at the time I didn't realise how strongly ingrained it was that a man would never do the washing.

Despite the seeming simplicity and apparent triviality of the point at issue, the story invites some complex questions about the teacher's use of authority and expertise in the different spaces constructed by the lesson, the conflation of English language and Western cultural norms, and the congruence between gendered space inside the classroom and in the domestic sphere. In particular, the juggling of gender and other aspects of cultural positioning in the teacher's stance is of interest in thinking about the use of teacher authority, and highlights the potential of multiple meanings in the event. Of these multiple meanings, two are perhaps more obvious: on the one hand, we might see in this story a pedagogical move towards gender equality, with the teacher's introduction of 'enlightening lenses'. On the other hand, we might see an imposition of Western assumptions and generalisations about gendered cultural relations made through the eyes of Western discourse, in effect an enactment of the 
racist and classist ‘civilising legacies’ of English language work (Schenke 1991). As critical scholars have pointed out, the construction of 'Third World' women and men as subjects of patriarchy based on "less rational and enlightened cultural norms" reproduces the idea of the "superiority of the West", diminishes the significance of race, class and nation, particularly their relation to colonial heritage, and assumes that Western women are liberated and in control of their own lives (Mohanty 2003, p. 41). With these conflicting meanings available, it seems that for Western teachers in development contexts the question of whose gender 'norms' are to be applied is critical.

In this incident, when the teacher moved outside of the classroom, she saw herself as retaining the spatialised authority to organise and attribute meanings in the domestic space where different aspects of gender and culture came into play. The balance between norms of gender equality and cultural sensitivity when 'applied' to the students became more difficult in a non-institutional space, and was perhaps intensified by the requirement for a bodily, 'hands-on' performance of gender that seemed to provoke a degree of resistance. Within a liberal framework of equality ('everybody has to ...') and tolerance towards difference ('it wasn't Western education ... was better'), a set of generalised cultural assumptions were implied: about the civilised behaviours of English language speakers, about the reach of the Western institution, about Australian and Timorese gender relations in domestic space, about freedom of individual 'choice'. The invocation of cultural appropriacy also opened questions of which cultural and practical context is assumed to be relevant, leaving a rather shaky connection between the language lesson and context of use. These tenuous connections indicate some of the sticky areas that are inherent 
in such 'mobile' practices of EAP, leaving the teacher in a difficult intersection at the boundary between Western notions of gender and the domain of cultural sovereignty that remains 'unknowable’ when opportunities for interrogation and inquiry are bypassed.

Moreover, a closer look at the distribution of labour in the immediate development context demonstrates clearly how gender is entangled with other dimensions of difference. My own observations of the domestic activity in expatriate houses revealed that white teachers, whether men or women, never did the washing up. This was a task assigned to the Timorese domestic workers who performed this labour for expatriate professionals while they, in turn, worked in the public domain. It seems that in this intercultural context, the salient hierarchies relevant to the division of labour were racial and economic rather than gendered.

\subsection{Dana: gender and pedagogical order}

While most of the teachers assumed the institutional authority to control the space of the classroom, the performance of authority was nevertheless contingent; as we have seen in Elly and Kate's experience, pedagogical authority relied on student consent. In Dana's experience, the teachers' authority was tempered by her awareness that she was an outsider on someone else's turf, and openly contested by one male student's behaviour.

In the campus where Dana’s program was located, the students had urged international agencies to provide an English language program to support their tertiary studies and had also, in the hiatus that followed the withdrawal of Indonesian 
authority, been granted 'ownership' of the site where the program was conducted. The majority of the students were young, politically active males, a number of whom had been actively involved in the fight for liberation. In this context, normal presumptions of teaching and administrative authority were at times challenged by expressions of student authority. The teaching space was a highly contested site and several teachers commented that they modified their usual performance of authority in consideration of their own status as 'outsiders' teaching in a cultural space where their own institutional authority was somewhat tenuous. For Dana, the youngest of the female teachers, the experience of teaching in the student controlled campus was particularly unsettling. Her story demonstrates how the normal 'rules' that prescribe the performance of authority in the space of the classroom were disturbed by the unexpected eruption of performances that, from the teacher's point of view, belonged outside the classroom, but were enabled by the gendered relation between the young female teacher and young male students.

As a relatively recent university graduate, Dana expressed a sense of being 'out of place' in the position of authority on the campus: 'I found the whole situation of being there pretty tricky'.

I remember walking in on that first day and it feeling a little bit um, intimidating, and um ... I don't know ... on the one hand it was great to be working in the university, but it was weird to be um, like, the university administration, where you know, we'd been used to, I'd been used to being the student when I was on campus, so it was kind of weird to be in a different role. 
Her sense of place was further disrupted as she became aware of the political implications of the teaching role. Based on her experience of teaching EAP in Australia, she believed that politics did not belong 'in the classroom', but because of the contested nature of the physical site she gradually became aware of the political position she occupied:

I remember those first couple of meetings we had [between teachers and student leaders] and there were problems with organisation and all that kind of stuff. That was quite sort of disorienting, 'cause we were there to just teach and there were all these political problems and that was sort of quite- was a little bit difficult at the start.

The teacher's unease focused on an incident in her classroom where one student, angry with the perceived misadministration of the program, stood up in class to make a public declaration. There was a long list of complaints with one particular accusation that Dana felt was 'totally justified': that the students 'should have been taught in Indonesian', by Indonesian-English bilingual teachers. As a monolingual language teacher, Dana saw herself as the victim of institutional and disciplinary policies that favoured native speakers of English:

I felt horrendous. I felt attacked. And pretty kind of freaked out. I found it was very hard not to take it on personally as a criticism of my teaching, 'cause there I was teaching in English, you know, because I'd been put in that position. 
Dana surmised that the student's challenge to her authority was probably related to his history of involvement in student politics, the liberation struggle, and 'fighting the Indonesians'. This 'culture of political activism' had been transferred into the classroom, but in her view 'it was not the appropriate forum to raise the issues that he was raising'. An example, perhaps, of learner-centred democracy gone too far? At the same time, the contestation by a male student also recalled for Dana her own gendered embodiment. As the teacher's sense of the normal reading of her (institutionally and spatially attributed) authority slipped, an evocation of the gendered vulnerability she had also experienced in the masculine, militarised environment outside the classroom surfaced: 'I always find that as a young female teacher that you always get challenged a bit more, because of your gender and because of your age'.

I don't think he would have done that in [a male teacher's] class for example. And you know, I think I was less confident at that point too, so as soon as you've got a young female teacher who isn't maybe quite as confident as, say an older male teacher, sometimes that can be tricky.

Following this incident Dana's level of comfort, and related expectations of control in the classroom, appeared to be compromised by the fear of potential challenges from her male students. Although Dana perceived herself as needing to be in control of the classroom through the repetition of well prepared and predictable routines, this space now became one of uncertainty:

I found it difficult to relax with the students, I found it difficult to relax with them. And you know, there were times when I was a little bit, um, a little bit wary of what 
was gong to happen next, um, that was mainly with the male students, some of the younger male students.

In this space, simultaneously constituted by the weight of educational authority, by gendered hierarchies, and by a student politics of liberation struggles, who gets to be 'standing up in class and doing the speech'? One reading of this classroom event might suggest that the contest of power relations signalled a confrontation between the ‘normal' male-dominant gendered hierarchy and the pedagogical hierarchy between female teacher and male student. In such events, there is a "point of confusion” that results from trying to think the gender relation ('male-female games') and the pedagogical relation ('student-teacher games') at the same time (Gallop, 1995, p. 85). In such a challenge, Gallop suggests that the "awkward question of sex" arises: the sexed bodies of teacher and student are materialised, and the assumed institutional authority of the teaching position is compromised by the reduction of the teacher to the space of her sexed body. As Gallop wryly comments with a "crude and schematic" but nevertheless “apt” observation: "However much the teacher might dream of divesting her- or himself of authority so as to get closer to the female student, she or he clearly does not want it taken away by the insubordinate male student (Gallop, 1995, p. 80).

In this context the added complication of the teacher being a cultural and political outsider, rather than in a position of institutional ownership and control, further confused what could be considered 'appropriate' in this contested space, and points to a reading that focuses on the student's challenge to traces of cultural imperialism in the structuring of the educational program. In this sense, our focus shifts away from 
the bodies of the individual female teacher and the individual male student, to the location of gender within international English language teaching and development policies and practices that disadvantaged both the teachers and students.

\subsection{Jane: gender in public and private space}

Cultural sensitivity, and an awareness of not necessarily being in a position of 'knowing', was evident in Jane's account of negotiating gender issues that surfaced inside the classroom. Her experiences in an EAP professional development program indicated the complex movement of gender between a public, institutional space of the school, and a private space of home and family.

In the [class] I had a woman who- she came in one day with a black eye and word had it that her husband had bashed her, but it was very much, 'Don't talk about it, don't mention it'. [...] She came in and she was very- there were two women and one sort of protected the other, like, she kind of slid into the seat, [although she normally] never sat to the back of the room, she was always at the front, and she and this friend sat up the back, close to the window. I guess from body language, I knew she had been abused. [...] The one that had been abused was sitting against the wall, so the other one-so there was no way that I could get around her.

Jane felt her students actively separated from the classroom space issues she assumed were related to on-going gender relations in their personal lives. In a class of students she described as 'quiet' and less 'politically active', her account of this event suggested how the students used the organisation of space within the classroom to 
keep private issues secluded from the institutional gaze. This created a deal of uncertainty for the teacher in knowing whether or how to acknowledge the situation:

Jane: I certainly needed to go back to the college [administration], back to the [person in charge] and say, 'What do I do, how do I deal with this? Or don't I? Or, what is I?' [..]

[Athor]: So how did you decide to deal with it?

Jane: Um, I didn't. I didn't like myself for not doing anything, um, and- but I did speak about it, not about it [in class], I sought guidance in it.

Jane's deliberations indicated a pull towards a nurturing discourse in which the teacher felt responsibility to act by extending her pedagogical interest into the private domain of family life. Her institutional inquiries confirmed her suspicions that her student had been identified as a victim of domestic violence. However, her pedagogical scrutiny of the incident risked aligning her with an intrusive and coercive institutional agenda of social monitoring and regulation. In the event, Jane spoke with another expatriate development worker and related the discussion they had:

Well okay, what can you do? You can say, 'You need to go somewhere', [but] where does this woman go when this happens? Um, there is nowhere for her to go. You can say, 'Come here' [to my house], and then you have- then you are- you don't know culturally what you're doing. 
Clearly, engaging with students' lived experience requires a need for sensitivity in the balance between teachers' authority and student privacy, between the institutional, panoptic spaces of the classroom and the private worlds that students may not want to have colonised by the institutional gaze. As professional practitioners of EAP, and as cultural outsiders, most teachers, like Jane, avoided explicitly raising gender as a topic for discussion into their classroom teaching, and instead allowed students to regulate the extent and the ways in which it was explicated.

Unlike Kate’s story, Jane’s account does not confine the problem in question to a specific culture or national location, thereby avoiding the implication that gendered violence was a problem that had been solved in the West, or could be solved in the ‘Third World’ by Western intervention. The teacher's deliberations suggested how the sensitive issue of gender relations linked, in an unspoken way, the otherwise discreet spaces of the home, the community and the classroom, demonstrating how the social, cultural and spatial aspects of the dilemma were mutually constituted. Yet, despite this tacit intersection with the classroom, the boundaries marked by the students limited the teacher's authority and involvement in these experiences, and in turn constrained her authority within the classroom to approach a significant issue of gender relations. These constraints were personally frustrating, but were also professionally problematic, given the intertwining of social relations and language work, the complex positioning of female teachers within the social networks of foreign contexts (for example, Simon-Maeda, 2004), and policy requirements for the incorporation of approaches to "overcome constraints to gender equality” in development programs (AusAID, 2002, p. 7). Although the public and private 
domains do intersect in the classroom, negotiating the line that divides the two is a challenging balancing act for teachers of EAP.

\section{Conclusion}

In the teachers' narratives, we can begin to see some of the challenges that face teachers when attending to gender as a dynamic dimension of their intercultural EAP practice. The paradoxes evident in their narratives indicate some of the contradictory discourses within which the language teacher must perform, working within a framework that confers institutional authority, yet responding to a call to democratise the classroom; working against perceived gender inequalities, while remaining sensitive to cultural difference, and to the heterogeneity within that cultural difference. Although international development policies that frame the teachers’ work propose an ideal temporal narrative of progress for gender equality, the teachers' dilemmas and difficulties highlight a challenge to the imposition of Western feminist norms in other cultural contexts, and are evidence of a practice that comprises significant complexities and contradictions. The relative detachment of the classroom from the world beyond allowed the teacher, in some instances, to establish certain 'gender rules' applicable to the contained space of the classroom, but this authority did not necessarily extend to an engagement with cultural practices of gender as they were experienced in the world outside the classroom.

In Elly's and Kate’s stories, I focused on accounts of teachers’ perceptions and performances of gendered authority, in the first instance located in the conventional public space of institutional EAP education, and in the second event, crossing into the domestic space. While the authority to organise classroom space and time to ensure 
gender equality in access to resources appeared to be relatively unproblematic in the first case, the physical shift from the classroom to the domestic domain potentially opened up more difficult questions of cultural difference and the knowability of gendered meanings in other spaces. The transfer of the teacher's institutionally conferred authority raised questions about the privilege of a foreign 'expert' to ascribe the appropriate norms and gendered meanings within another cultural context for EAP. Although the spatial shift outside the institution could potentially be used to open further inquiry about multiplicity in gender and culture relations, such an interrogation could also be seen as an intrusive extension of the institution into other cultural spaces. The spatial shift from public to private, and across cultural boundaries, thus opens a difficult area for teachers as local gender relations become an object of improvement, potentially enabling the relics of colonial hierarchy to be reinscribed in the civilising legacies of English language work.

Far from describing a linear progress towards emancipatory goals, Dana’s and Jane's accounts demonstrated how teaching spaces were co-constructed through the various gendered relations and meanings brought to the classroom by teachers and students. As outsiders to East Timorese politics, history and culture, the institutional authority exercised by the teachers was rendered tenuous. Their authority was relational and dependent, tied up with territoriality, students' agency in contesting spatial meanings, and rights to ownership and privacy. Gendered meanings were entangled with culturally and contextually embedded patterns of public and private space that also limited the authority of the First World teacher to institute normative 'visions' of social justice. The authority of the female teacher was structured in a complex set of power, gender and knowledge relations within the classroom, and between the 
classroom and communities beyond the classroom walls. In these difficult circumstances, there is value in "remaining open and vulnerable" to "what is not, or cannot, be fully known and controlled” (Ellwood, 2006, p. 68), staying within the grey area of uncertainty, rather than rushing to a quick success by advancing principles gender equality derived from a position of cultural superiority.

Challenges to teacher authority to control the pedagogical space and to fix gendered meanings were evident in the teachers' narratives, and highlight the extent to which the teachers' authority is dependent not only on the institutional location of the classroom, but also on the cooperation of students. Students' contestation of authority was expressed in various embodied performances, with a reluctance to relinquish seating positions, with 'eyes as big as saucers', in standing up to deliver a speech, with a shielding of bodies to prevent teacher access. While these challenges to the female teachers' authority were frustrating in some cases, they also potentially opened the way to greater awareness of the struggle over multiple differences inscribed within the classroom and in the context outside the classroom, and provoked several of the teachers to reflect on the limits of First World pedagogical practice in approaching the issue of gender.

The teachers' accounts have demonstrated that even when gender is not an explicit focus of English language teaching, it emerges in classroom events from the discourses and experiences students and teachers bring to the classroom. In attending to these events, we have seen that teachers varied in the extent to which they identified with and enacted Western institutional authority in regard to questions of gender politics and cultural sensitivity. For most of these teachers in the development 
context, it was not simply a matter of acting with authority to help their students towards enlightenment or to develop intercultural 'competence' in gender issues. Rather, their pedagogical practice was a matter of working in a borderland that was inscribed with strong but contradictory demands for teachers to join the struggle for 'knowable' human rights, and simultaneously to respect an 'unknowable' local cultural politics. Although teachers may be able to take up the authority conferred by the institution, their privileged position in racial and economic politics of difference and their status as cultural outsiders, limits the extent to which they can speak and act on issues of gender.

\section{Appendix: Codes used in interview transcriptions}

[...] - some original text omitted

.. - pause

[text] - not stated by interviewee, but inserted by researcher to ensure clarity of grammatical or referential meaning

text- - speaker self-interrupts

text - indicates emphasis by speaker

[text] - includes description of the non-verbal (laughter and gesture)

\section{References}

AusAID (2007a). Better Education: A Policy for Australian Development Assistance in Education. Canberra: Australian Agency for International Development. AusAID (2007b). Gender Equality in Australia's Aid Program - Why and How. Canberra: Australian Agency for International Development. 
AusAID (2002). Gender and Development: GAD lessons and challenges for the Australian aid program. Canberra: Australian Agency for International Development.

Belcher, D. (2006). English for specific purposes: teaching to perceived needs and imagined future in worlds of work, study, and everyday life. TESOL Quarterly, 40(1), 133-156.

Bowcott, O. (2005). Report reveals shame of UN peacekeepers. Retrieved 8 January 2007, from http://www.guardian.co.uk/international/story/0,,1445537,00.html

East Timor Institute for Reconstruction Monitoring and Analysis (2001) Women and the reconstruction of East Timor. La'o Hamutuk Bulletin, 2(5). Retrieved 2 January 2007, from http://www.laohamutuk.org/bulletin.html

Ellsworth, E. (1989). Why doesn't this feel empowering? Working through the repressive myths of critical pedagogy. Harvard Educational Review, 59, 297324.

Ellwood, C. (2006). On coming out and coming undone: Sexualities and reflexivities in language education research. Journal of Language, Identity, and Education, 5(1) 67-84.

Enloe, C. (2000). Maneuvers: The International Politics of Militarizing Women's Lives. Berkley: University of California Press.

Escobar, A. (1995). Encountering Development: The Making and Unmaking of the Third World. Princeton: Princeton University Press.

Gallop, J. (1995). The teacher's breasts. In J. Gallop (Ed.), Pedagogy: The Question of Impersonation (pp. 79-89). Bloomington and Indianapolis: Indiana University Press.

Jones, D. M., (1990). Genealogy of the urban schoolteacher. In S. J. Ball (Ed.), 
Foucault and Education (pp. 57-77). London: Routledge.

Lather, P. (1992). Post-critical pedagogies: A feminist reading. In C. Luke \& J. Gore (Eds.), Feminisms and Critical Pedagogy (pp. 120-137). New York:

Routledge.

Luke, C. (1992). Feminist politics in radical pedagogy. In C. Luke \& J. Gore (Eds.), Feminism and Critical Pedagogy (pp. 25-53). New York: Routledge.

Luke, C. (1996). Feminist pedagogy theory: Reflections on power and authority. Educational Theory, 46(3), 283-302.

Luke, C., \& Gore, J. (Eds.). (1992). Feminism and Critical Pedagogy. New York: Routledge.

Massey, D. (1994). Space, place and gender. Cambridge: Polity Press.

Mazurana, D. (2005). Gender and the causes and consequences of armed conflict. In D. Mazurana, A. Raven-Roberts, J. Parpart, \& J. Lautze, (Eds). Gender, Conflict, and Peacekeeping (pp. 29-42). Lanham: Rowman \& Littlefield.

Mazurana, D., Raven-Roberts, A., Parpart, J. \& Lautze, J. (2005). Gender, Conflict, and Peacekeeping. Lanham: Rowman \& Littlefield.

McWilliam, E. (1999). Pedagogical Pleasures. New York: Peter Lang.

Mohanty, C. T. (2003). Feminism Without Borders: Decolonizing Theory, Practicing Solidarity. Durham and London: Duke University Press.

Mohanty, C. T. (1988). Under Western eyes: Feminist discourse, scholarship and colonial discourses. Feminist Review, 30, 60-88.

Norton, B., \& Pavlenko, A. (2004). Addressing gender in the ESL/EFL classroom. TESOL Quarterly, 38(3), 504-514.

Pennycook, A. (1994). The Cultural Politics of English as an International Language. London: Longman. 
Pennycook, A. (1997). Vulgar pragmatism, critical pragmatism, and EAP. ESP Journal 16(4) 253-269.

Pennycook, A. (1998). English and the Discourses of Colonialism. London: Routledge.

Pennycook, A. (2001). Critical Applied Linguistics: A Critical Introduction. Mahwah, NJ: Lawrence Erlbaum.

Phillipson, R. (1992). Linguistic Imperialism. Oxford: Oxford University Press.

Schenke, A. (1991). The 'will to reciprocity' and the work of memory: Fictioning speaking out of silence in E.S.L. and feminist pedagogy. Resources for Feminist Research, 20, 47-55.

Schenke, A. (1996). Not just a 'social issue': Teaching feminist in ESL. TESOL Quarterly, 30(1), 155-159.

Singh, P. \& Doherty, C. (2004). Global cultural flows and pedagogic dilemmas: teaching in the global university contact zone. TESOL Quarterly, 38(1), 9-42.

Simon-Maeda, A. (2004). The complex construction of professional identities: Female EFL educators in Japan speak out. TESOL Quarterly, 38(3), 405-436.

Spurr, D. (1993). The Rhetoric of Culture: Colonial Discourse in Journalism, Travel Writing and Imperial Administration. Durham: Duke University Press.

Stoler, A. L. (1995). Race and the Education of Desire: Foucault's History of Sexuality and the Colonial Order of Things. Durham: Duke University Press.

Sunderland, J. (2000). Issues of language and gender in second and foreign language education. Language Teaching, 33, 203-223.

Sunderland, J. (2004). Classroom interaction, gender, and foreign language learning. In B. Norton \& K. Toohey (Eds.), Critical Pedagogies and Language Learning (pp. 222-241). Cambridge: Cambridge University Press. 
Thomas, P. (2004). Gender and development: Bridging policy and practice.

Development Bulletin, 64, 4-7.

Wells, J., \& McEwan, T. (2004). Gender mainstreaming: Moving from principles to implementation. Development Bulletin, 64, 31-33. 


\title{
The spatial politics of gender in EAP classroom practice
}

\author{
Roslyn Appleby \\ University of Technology, Sydney \\ Postal Address: \\ The ELSSA Centre \\ University of Technology, Sydney \\ PO Box 123 \\ BROADWAY \\ NSW 2007 \\ AUSTRALIA \\ Email: $\quad$ Roslyn.Appleby@uts.edu.au \\ Telephone: $\quad$ +61 2 9514-1490(w) \\ +61 2 9907-0601 (h) \\ Biography: \\ Roslyn Appleby is a Senior Lecturer at the University of Technology, Sydney, where \\ she teaches and coordinates language and literacy programs within several faculties. \\ Her research focuses on postcolonial and feminist perspectives in international \\ English language education.
}

